\title{
The Effect of Lysozyme on Cell Wall Morphology in a Blue-green Alga, Cylindrospermum sp.
}

\author{
By T. E. JENSEN AND LINDA M. SICKO \\ Department of Biological Sciences, Herbert H. Lehman College of the \\ City University of New York, Bronx, New York, U.S.A. \\ (Accepted for publication 26 June I97I)
}

\begin{abstract}
SUMMARY
Electron micrographs of thin sections of the wall of a Cylindrospermum sp. treated with lysozyme show that layer 2 (intermediate layer) of the wall is removed. Hence this layer is composed of mucopolymer. This observation, and the previous reports that this layer is thickened in mature spores of a Cylindrospermum $\mathrm{sp}$. and in vegetative cells of Oscillatoria princeps, suggest that mucopolymer determines wall strength and maintains cell shape.
\end{abstract}

\section{INTRODUCTION}

Various terms have been used to describe wall structure in blue-green algae. Pankratz \& Bowen (1963) describe the wall as three-layered while Jost (1965) considers it to be fourlayered. In this paper the terminology of Jost (I965) will be used. Using this terminology the wall of blue-green algae, starting with the innermost layer and proceeding outward, consists of: an electron-transparent layer (I) immediately outside the plasma membrane; an electrondense layer (2); an electron-transparent layer (3); and an outer electron-dense layer (4). Which of these layers contains the mucopolymer described in walls of blue-green algae (Frank, Lefort \& Martin, 1962a, b; Drews \& Meyer, I964; Hock, Martin \& Kandler, I965) has not been conclusively demonstrated. Frank et al. (I962b) suggests that it is the electron-transparent layer (layer I) while others (Allen, I968; Lamont, 1969) suggest that it is layer 2. We therefore decided to use lysozyme, which is known specifically to remove the mucopolymer, to determine more precisely the location of this wall component. A number of investigators have described the effects of lysozyme on blue-green algae in producing spheroplasts (Fuhs, I958; Crespi, Mandeville \& Katz, I962; Fulco, Karfunkel \& Aaronson, 1967; Vance \& Ward, I969) but these studies were confined to light microscopic observations.

\section{METHODS}

Cylindrospermum sp. Indiana University Culture Collection no. LB 942 (Starr, I964) was grown in Chu's medium ro with soil extract (Chu, I942). Cultures were maintained at $2 \mathrm{I}^{\circ}$ under $500 \mathrm{ft}$ candles of illumination with a $\mathrm{I} 2 \mathrm{~h}$. alternating light and dark period.

Samples were fixed in $3 \%$ glutaraldehyde in $0 . \mathrm{I} \mathrm{M}$-phosphate buffer at $\mathrm{pH} 7.2$ for $\mathrm{I} \mathrm{h}$. at $4^{\circ}$ and then thoroughly rinsed in buffer. For lysozyme treatment the method of Murray, Steed \& Elson (1965) was followed: the algae were suspended in $0.3 \mathrm{M}$-tris buffer at $\mathrm{pH} 8.0$ containing I34 $\mu \mathrm{g}$. EDTA $/ \mathrm{ml}$., $68 \mu \mathrm{g}$. lysozyme $/ \mathrm{ml}$. (Worthington, twice crystallized) and $10 \% \mathrm{w} / \mathrm{v}$ sucrose. After $8 \mathrm{~h}$., $\mathrm{MgSO}_{4} \cdot 7 \mathrm{H}_{2} \mathrm{O}$ was added to $0.05 \mathrm{M} ; \mathrm{I} / 2 \mathrm{vol} .40 \%$ sucrose was then added. The samples, after rinsing in distilled water, were placed in Michaelis buffer 

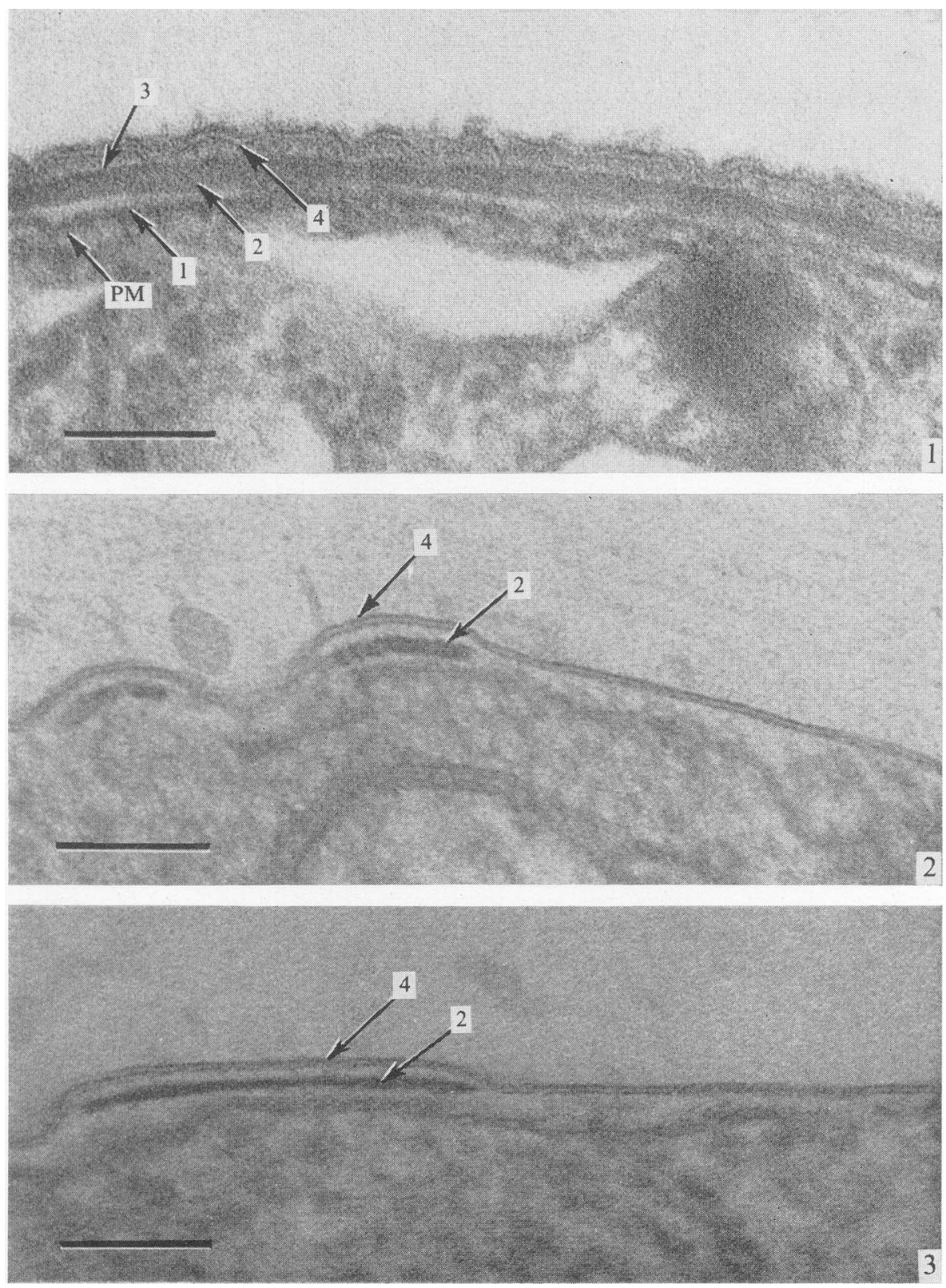

Fig. I. Portion of the wall of untreated Cylindrospermum sp. showing the successive layers. Immediately outside the plasma membrane (PM) is layer $\mathbf{I}$. This is followed by the electron-dense layer 2, by the electron-transparent layer 3, and the outer layer 4 which shows its double-track membrane nature and characteristic undulations. Bar $=100 \mathrm{~nm}$.

Fig. 2. Portion of the wall of Cylindrospermum sp. treated with lysozyme. Portions of layer 2 still remain. The outer layer is continuous over the missing segments. Bar $=100 \mathrm{~nm}$.

Fig. 3. Portion of the wall treated with lysozyme. One portion of the layer 2 still remains. The outer layer is continuous. Bar $=100 \mathrm{~nm}$. 
at $\mathrm{pH} 6 \cdot \mathrm{I}$ overnight. The samples were then fixed in $\mathrm{OsO}_{4}(\mathrm{I} \% \mathrm{w} / \mathrm{v})$ according to the method of Pankratz \& Bowen (1963).

After fixation the samples were dehydrated rapidly in a graded ethanol series, treated with propylene oxide and embedded in Epon 8I2 (Luft, r96I). Sections cut with a diamond knife on an LKB Ultrotome were stained with uranyl salts and examined with an electron microscope.
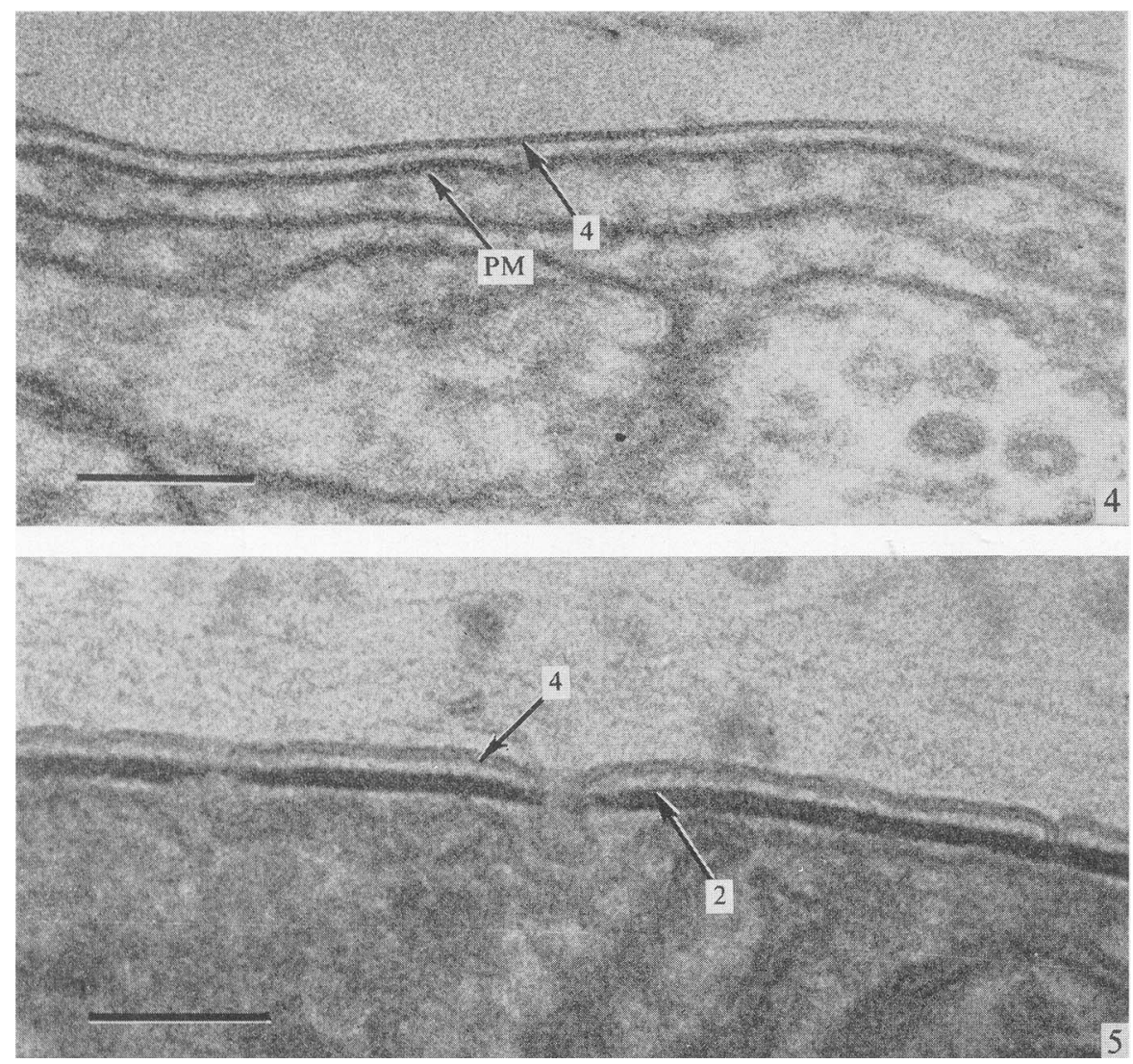

Fig. 4. Portion of the cell wall of Cylindrospermum sp. treated with lysozyme in which layer 2 is no longer visible. The outer layer and the plasma membrane (PM) are continuous. Bar $=100 \mathrm{~nm}$.

Fig. 5. Portion of the cell wall of Cylindrospermum sp. treated with lysozyme showing the invagination of the outer layer through a missing segment in layer 2 . Bar $=100 \mathrm{~nm}$.

\section{OBSERVATIONS}

Fig. I shows the four layers of the wall of Cylindrospermum sp. The electron-transparent layer $\mathrm{I}$, about $3 \mathrm{~nm}$. thick, surrounds the plasma membrane; in an outward direction it is followed by the electron-dense layer 2, about $10 \mathrm{~nm}$. thick, another electron-transparent layer 3 , about $3 \mathrm{~nm}$. thick and the outer layer 4 , consisting of a double-track membrane about $8 \mathrm{~nm}$. thick and with characteristic undulations.

In material treated with lysozyme for $8 \mathrm{~h}$. portions of layer 2 were missing in some cells (Fig. 2, 3), while in others the layer was completely absent (Fig. 4). The outer layer 4 was 
continuous across these missing segments of layer 2 . In sections of material in which most of layer 2 had been removed much distortion was observed.

Digestion by lysozyme appeared to start in one area with the formation of a small 'hole' through layer 2. Fig. 5 shows the outer layer 4 drawn into an area from which layer 2 had been removed. This movement of the outer layer into the cell was probably caused by some plasmolysis when the sample was placed in the last sucrose solution.

\section{DISCUSSION}

Murray et al. (1965) have shown that lysozyme digestion removes the layer 2 (intermediate) from walls of Gram-negative bacteria. Our results show that this layer is also removed from the walls of a blue-green alga, Cylindrospermum sp., exposed to lysozyme. Thus in Gram-negative bacteria and in blue-green algae the mucopolymer seems to be concentrated in layer 2.

Murray et al. (1965) have suggested that this layer determines the strength of the wall and thus aids in maintaining the shape of the organism. The previous report by Jensen \& Clark (I969), that in mature spores of a Cylindrospermum sp. layer 2 is thickened, supports this concept. The vegetative cells in this organism are approximately 4 to $5 \mu \mathrm{m}$. in diameter by 4 to $7 \mu \mathrm{m}$. long while the spore is approximately 8 to Io $\mu \mathrm{m}$. wide by $\mathrm{I} 4$ to $\mathrm{I} 8 \mu \mathrm{m}$. long. With an increase in cell size one would expect an increase in the material which aids in maintaining its shape. This concept is also supported by the fact that in the blue-green alga Oscillatoria princeps, whose cell diameter is about $40 \mu \mathrm{m}$., this layer is also thicker. Layer 2 is up to $0.4 \mu \mathrm{m}$. thick compared to the average thickness of about $10 \mathrm{~nm}$. reported for other vegetative cells of the blue-green algae (Jensen, 1965). It therefore appears that in this case also the necessity of increased strength in the wall to maintain the shape of the larger cell is solved by increasing the thickness of the mucopolymer layer.

These observations provide evidence for our proposal that layer 2 is composed of mucopolymer. The composition of the other layers found in blue-green algal cell walls must await further analysis.

This investigation was supported in part by National Science Foundation grant GB 6305 .

\section{REFERENCES}

ALLEN, M. M. (1968). Ultrastructure of the cell wall and cell division of unicellular blue-green algae. Journal of Bacteriology 96, 842-852.

CHU, S. P. (1942). The influence of the mineral composition of the medium on the growth of planktonic algae. I. Methods and culture media. Journal of Ecology 30, 284-325.

Crespi, H. L., Mandeville, S. E. \& KATz, J. J. (1962). The action of lysozyme on several blue-green algae. Biochemical and Biophysical Research Communications 9, 569-573.

Drews, G. \& MeYer, H. (1964). Untersuchungen zum chemischen Aufbau der Zellwände von Anacystis nidulans und Chlorogloea fritschii. Archiv für Mikrobiologie 48, 259-267.

Frank, H., Lefort, M. \& Martin, H. H. (I962a). Chemical analysis of a mucopolymer component in cell walls of the blue-green alga Phormidium uncinatum. Biochemical and Biophysical Research Communications $7,322-325$.

FrANK, H., LEFORT, M. \& MARTIN, H. H. (I962 b). Elektronenoptische und chemische Untersuchungen an Zellwanden der Blaualge Phormidium uncinatum. Zeitschrift für Zellforschung und Mikroskopische Anatomie 176, 262-268.

FuHs, G. W. (1958). Enzymatischer Abbau der Membranen von Oscillatoria amoena (Kutz.) Gomont mit Lysozym. Archiv für Mikrobiologie 29, 5I-52. 
Fulco, L., Karfunkel, P. \& Aaronson, S. (1967). Effect of lysozyme (muramidase) on marine and fresh. water blue-green algae. Journal of Phycology 3, 5r-52.

Hock, H., Martin, H. H. \& Kandler, O. (I965). Zur Kenntnis der chemischen Zusammensetzung der Zellwand der Blaualgen. Zeitschrift für Pflanzenphysiologie 53, 39-57.

Jensen, T. E. (1965). The fine structure of certain members of the order Nostocales. Ph.D. Thesis, Iowa State University, Ames, Iowa.

Jensen, T. E. \& ClaRK, R. L. (I969). Cell wall and coat of the developing akinete of a Cylindrospermum sp. Journal of Bacteriology 97, I494-I495.

Jost, M. ( I 965). Die Ultrastruktur von Oscillatoria rubescens D.C. Archiv für Mikrobiologie 50, 2 I I-245.

LAMONT, H. C. (1969). Shear-oriented microfibrils in the mucilaginous investments of two motile oscillatoriacean blue-green algae. Journal of Bacteriology 97, 350-36I.

LUFT, J. H. (I96I). Improvements in epoxy resin embedding methods. Journal of Biophysical and Biochemical Cytology 9, 409-4I4.

Murray, R. G., Steed, E. P. \& Elson, H. E. (1965). The location of the mucopeptide in sections of the cell wall of Escherichia coli and other Gram-negative bacteria. Canadian Journal of Microbiology rr, 547560.

Pankratz, H. S. \& Bowen, C. C. (1963). Cytology of blue-green algae. I. The cells of Symploca muscorum. American Journal of Botany 50, 387-399.

STARr, R. C. (1964). The culture collection of algae at Indiana University. American Journal of Botany 5r, IOIO-IO44.

VANCE, B. D. \& WARD, H. B. (1969). Preparation of metabolically active protoplasts of blue-green algae. Journal of Phycology 5, 1-3. 